\title{
How important is inert organic matter for predictive soil carbon modelling using the Rothamsted carbon model?
}

\author{
Pete Falloon $^{\mathrm{a}, *}$, Pete Smith $^{\mathrm{a}}$, Kevin Coleman ${ }^{\mathrm{a}}$, Stewart Marshall ${ }^{\mathrm{b}}$ \\ ${ }^{a}$ Soil Science Department, IACR-Rothamsted, Harpenden, Hertfordshire AL5 2JQ, UK \\ ${ }^{\mathrm{b}}$ Environmental Science Division, School of Biological Science, University of Nottingham, Sutton Bonnington Campus, Loughborough, Leicestershire \\ $L E 125 R D, U K$
}

Received 8 April 1999; received in revised form 16 August 1999; accepted 2 September 1999

We show that modelled estimates of changes in soil organic carbon (SOC) resulting from changes in land use are affected by the estimate of inert organic matter (IOM), but that the errors introduced are less than those introduced by previously used methods for estimating changes in regional SOC stocks (e.g. Smith et al., 1997b, 1998a,b). The Rothamsted carbon model (RothC: Jenkinson and Rayner, 1977; Coleman and Jenkinson, 1996) is one of the earliest computer-based models for the turnover of soil organic matter (SOM). RothC has been widely used to simulate long-term trends in SOC across a range of land-uses, soil-types and climatic regions (Jenkinson et al., 1987, 1992; Coleman et al., 1997; Smith et al., 1997a). It as also been applied at the regional (Parshotam et al., 1995; Falloon et al., 1998a) and the global scale (Post et al., 1982; Jenkinson et al., 1991) to estimate net primary productivity, $\mathrm{CO}_{2}$ fluxes, or changes in SOC. In order to initialise the model, the user specifies the inert organic matter (IOM) content of the soil. IOM in RothC is defined as a fraction of soil organic matter that is biologically inert and has an equivalent radiocarbon age of more than 50,000 years. It is a device (Jenkinson et al., 1987) to allow the model to represent shortterm changes in SOM brought about by changes in land management, and at the same time to account for the great radiocarbon ages measured in surface soils collected before thermonuclear tests (i.e. prior to 1960), which caused a pulse of ${ }^{14} \mathrm{C}$ to enter the soil.

\footnotetext{
* Corresponding author. Tel.: +44-1582-763-133; fax: + 44-1582760-981.

E-mail address: pete.falloon@bbsrc.ac.uk (P. Falloon).
}

Chemically, it is almost certainly a mixture, made up of charcoal, which can be of any any age, geologically ancient coal, and organic material trapped irreversibly in the soil (Falloon et al., 1998b). The IOM content of soil varies markedly between sites (Tate et al., 1995; Falloon et al., 1998b). It has been suggested that the accurate specification of IOM is essential to modelling studies (Skjemstad et al., 1996) and that uncertainty in IOM estimates could be a major source of error in modelling SOC (Jenkinson et al., 1991; Parshotam et al., 1995; Schlesinger, 1995).

Direct estimation of the size of the IOM pool in soils requires paired soil radiocarbon-SOC measurements (Jenkinson et al., 1991, 1992, 1994, 1999a,b; Coleman et al., 1994, 1996; Jenkinson and Coleman, 1994; Parshotam and Hewitt, 1995; Tate et al., 1995; Falloon et al., 1998b). Since radiocarbon measurements are costly and rarely performed routinely, IOM has also been set at an arbitrary value (Parshotam et al., 1995; Coleman et al., 1997), or set to zero (Post et al., 1982; Wang and Polglase, 1995). It has also been set from an empirically-derived relationship between IOM and total SOC (Falloon et al., 1998a,b). The equation for this relationship (Eq. (1)), and its upper (Eq. (2)) and lower (Eq. (3)) 95\% confidence levels, are given below:

$\mathrm{IOM}=0.049 \times \mathrm{SOC}^{1.139}$

$$
\operatorname{IOM}(+95 \% \text { C.I. })=0.1733 \times \operatorname{SOC}^{1.4624}
$$

$\operatorname{IOM}(-95 \%$ C.I. $)=0.01384 \times \operatorname{SOC}^{0.8156}$ 
To determine whether uncertainties in IOM estimates could cause large errors in predicted future SOC values, we first investigated the effects of assuming different sized IOM pools on modelled SOC values at the site scale. We used long-term weather, soil and land management data to model the Rothamsted Geescroft Wilderness Experiment (previously modelled in Coleman et al., 1997). All model inputs were identical to those used by Coleman et al. (1997), except for the initial distribution of carbon amongst the model pools. We altered the initial pool size distribution by changing the IOM value (Table 1), but maintaining the same initial proportion of each of the other $\mathrm{C}$ pools in the model (decomposable plant material (DPM), resistant plant material (RPM), biomass (BIO) and humified organic matter (HUM)) to total SOC (original values set using radiocarbon data as in Coleman et al., 1997). Fig. 1 shows the effects upon the estimate of SOC of setting the IOM content as follows: (a) from using radiocarbon data, (b) from the regression of IOM on SOC (Eq. (2), Falloon et al., 1998b), and (c) from the upper and lower $95 \%$ confidence limits of this regression. Table 2 shows the root mean square error (RMSE; Smith et al., 1996, 1997a) values for these model runs, and the difference from the final predicted SOC content, with IOM set using radiocarbon data.

Using the regression to set IOM for RothC gives SOC predictions close $(\mathrm{RMSE}=6.41)$ to those obtained using radiocarbon data $(\mathrm{RMSE}=6.44)$. Similar results could not be expected for soils with large IOM contents, e.g. allophanic soils, waterlogged soils, highly organic soils, or soils containing large amounts of charcoal. With IOM set from the lower 95\% confidence interval of the regression, RothC slightly underpredicts total SOC (RMSE $=6.66$ ), but using IOM from the upper $95 \%$ confidence interval of the re-

Table 1

Pool sizes used in initializing RothC for investigating the effects of different proportions of IOM

\begin{tabular}{lcccc}
\hline & \multicolumn{2}{l}{ RothC IOM value set from } & & \\
\cline { 2 - 3 } & Radiocarbon $^{\mathrm{b}}$ & Lower $^{\mathrm{a}} 9 \%^{\mathrm{c}}$ & Regression $^{\mathrm{c}}$ & Upper $95 \%^{\mathrm{c}}$ \\
\hline DPM & 0.04 & 0.05 & 0.05 & 0.01 \\
RPM & 3.34 & 3.68 & 3.43 & 0.86 \\
BIO & 0.49 & 0.54 & 0.51 & 0.13 \\
HUM & 18.57 & 20.48 & 19.05 & 4.81 \\
IOM & 2.50 & 0.19 & 1.91 & 19.13 \\
Total & 24.94 & 24.94 & 24.94 & 24.94 \\
\hline
\end{tabular}

${ }^{\text {a }}$ IOM value used for RothC model run.

${ }^{\mathrm{b}} \mathrm{IOM}$ set using radiocarbon data.

${ }^{c}$ IOM set from the regression of Falloon et al. (1998b), from the lower $95 \%$ confidence interval of the regression, and from the upper $95 \%$ confidence interval of the regression. gressions results in a large overprediction in total SOC $($ RMSE $=19.46)$. The SOC values obtained after 110 yr (1993), by using IOM set from the upper and lower $95 \%$ confidence levels of the regression, result in differences of $(+) 18.54 \%$ and $(-) 0.66 \%$ from the radiocarbon-predicted value, respectively. These differences increase with time. Thus, uncertainties in IOM set from the regression could have a significant effect on SOC predictions at the site scale.

We also studied the effects of errors in IOM on largescale carbon sequestration estimates. To estimate the maximum error, we used the most effective scenario for increasing the SOC stocks of European arable land, described by Smith et al. (1997b, 1998a,b), i.e. afforestation of $30 \%$ of present arable land. We used $\mathrm{C}$ inputs, weather and land management based upon Geescroft Wilderness (Jenkinson et al. 1991; Coleman et al., 1997). We calculated the change in SOC stocks over $100 \mathrm{yr}$, using model runs with IOM set by: (a) radiocarbon data, (b) the regression (Falloon et al., 1998b) and (c) from the upper and lower $95 \%$ confidence intervals of the regression (Falloon et al., 1998b). The IOM values used for these runs are given in Table 1. We then applied the proportionate change in SOC stocks from these values to the current SOC stock of European arable land (Smith et al., 1998a). Table 3 shows the differences in SOC, and increases in total European SOC stocks predicted using IOM values set as described above, over $100 \mathrm{yr}$. The largest deviation from the change in SOC predicted using IOM set with radiocarbon data is that using IOM set from the upper $95 \%$ confidence interval of the regression. Given a total SOC stock $(0-30 \mathrm{~cm})$ for Europe of $34.64 \mathrm{Pg} \mathrm{C}$ (Smith et al., 1998a), the difference in the predicted change in SOC stocks over $100 \mathrm{yr}$ is $35.6 \%(0.85 \mathrm{Pg} \mathrm{C})$ for the area affected by the land use

Table 2

Root mean square error of RothC simulated SOC compared to measured data, and the difference from final SOC value as estimated by radiocarbon data

\begin{tabular}{|c|c|c|c|}
\hline & \multicolumn{2}{|c|}{ RothC IOM value set from ${ }^{a}$} & \multirow[b]{2}{*}{$\%$ Difference } \\
\hline & $\mathrm{RMSE}^{\mathrm{b}}$ & Difference $\left(\mathrm{t} \mathrm{C} \mathrm{ha}{ }^{-1}\right)^{\mathrm{c}}$ & \\
\hline Radiocarbon data ${ }^{\mathrm{d}}$ & 6.44 & 0.00 & 0.00 \\
\hline Lower $95 \%{ }^{\mathrm{e}}$ & 6.66 & -1.51 & -2.58 \\
\hline Regression $^{\mathrm{e}}$ & 6.41 & -0.39 & -0.66 \\
\hline Upper $95 \%{ }^{\mathrm{e}}$ & 19.46 & 10.86 & 18.54 \\
\hline \multicolumn{4}{|c|}{$\begin{array}{l}{ }^{\text {a }} \text { IOM value used for RothC model run. } \\
\text { b RMSE of paired modelled-measured points (Smith et al., 1996, } \\
\text { 1997a). } \\
\text { c Difference from } 1993 \text { SOC value of RothC when using radiocar- } \\
\text { bon data to set IOM value. } \\
{ }^{\mathrm{d}} \text { IOM set using radiocarbon data. } \\
{ }^{\mathrm{e}} \text { IOM set from the regression of Falloon et al. (1998b), from the } \\
\text { lower } 95 \% \text { confidence interval of the regression, and from the upper } \\
95 \% \text { confidence interval of the regression. }\end{array}$} \\
\hline
\end{tabular}




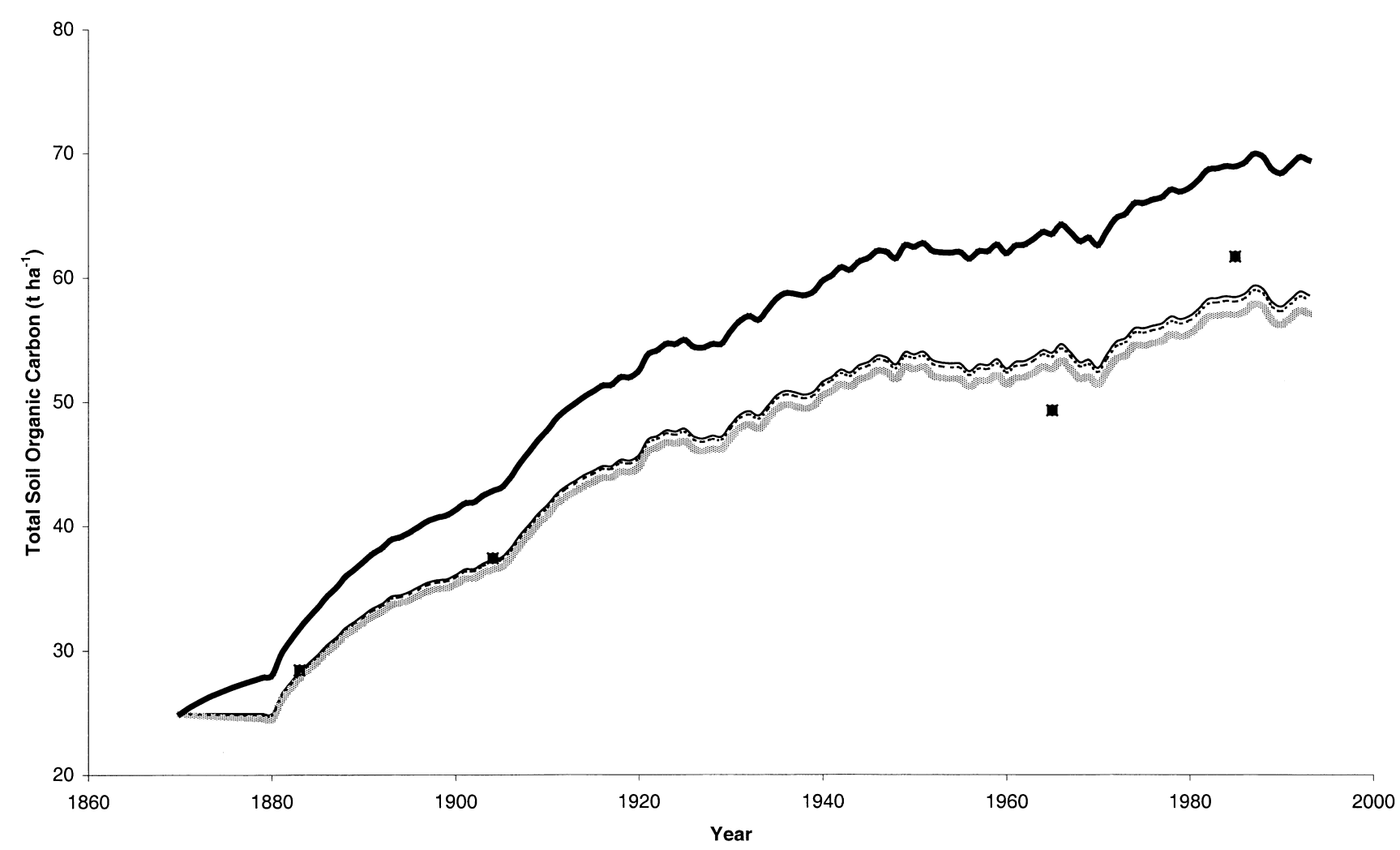

Fig. 1. Measured and RothC-predicted total SOC for the Geescroft Wilderness Experiment. (ם) Measured SOC; (一) RothC predicted SOC using IOM set from radiocarbon data; (- - ) RothC predicted SOC using IOM set using the regression of IOM on SOC; (dotted line) RothC predicted SOC using IOM set from the lower 95\% confidence interval of the regression; (-) RothC predicted SOC using IOM set from the upper $95 \%$ confidence interval of the regression.

change (i.e. the $30 \%$ arable land afforested). However, the difference in the predicted change in SOC stocks for the whole of Europe is $2.2 \%$, over $100 \mathrm{yr}$.

Our calculations indicate that the difference in the predicted change in SOC stocks may be as large as $35.6 \%$ within the area to which a change in land use or management is applied when IOM is set at the limit of its $95 \%$ confidence interval. Only a small error is introduced for the change in SOC stocks for Europe as a whole, since only $8.3 \%$ of the land area is affected by this scenario. The maximum error introduced by setting IOM using the upper $95 \%$ confidence interval is less than the error inherent in previous approaches for estimating regional $\mathrm{C}$ sequestration potential. Smith et al. (1998b) used a regression-based estimate in their scenario of conversion of all arable land to notill farming. The difference between their mean value and the upper $95 \%$ confidence interval for their regression was $53.2 \%$ for the change in SOC stocks of the area affected by the no-till scenario, or $5.9 \%$ for the change in the total European SOC stock. We conclude that, whilst the errors introduced by uncertain-

Table 3

Effects of different methods of setting the size of the IOM pool on the predicted SOC increase for European soils

\begin{tabular}{|c|c|c|c|c|c|}
\hline & $\begin{array}{l}\text { Initial SOC } \\
(\mathrm{t} \mathrm{C} \mathrm{ha-1)}\end{array}$ & $\begin{array}{l}\text { Final SOC } \\
\left(\mathrm{t} \mathrm{C} \mathrm{ha}^{-1}\right)\end{array}$ & $\begin{array}{l}\text { SOC difference } \\
\text { over } 100 \mathrm{yr} \\
(\mathrm{t} \mathrm{C} \mathrm{ha}\end{array}$ & $\begin{array}{l}\text { Increase in total } \\
\text { European } \mathrm{C} \text { stocks } \\
\text { over } 100 \mathrm{yr}^{\mathrm{a}}(\mathrm{Pg})\end{array}$ & $\begin{array}{l}\text { Predicted total SOC stock } \\
\text { after } 100 \mathrm{yr} \text { of afforestation of } \\
30 \% \text { arable land }(\mathrm{Pg})\end{array}$ \\
\hline IOM set by radiocarbon data & 24.94 & 52.73 & 27.79 & 2.40 & 37.04 \\
\hline IOM set using the regression ${ }^{b}$ & 24.94 & 52.37 & 27.43 & 2.37 & 37.01 \\
\hline IOM from upper $95 \% \mathrm{CI}^{\mathrm{b}}$ & 24.94 & 62.62 & 38.08 & 3.25 & 37.89 \\
\hline IOM from lower $95 \% \mathrm{CI}^{\mathrm{b}}$ & 24.94 & 51.35 & 26.41 & 2.28 & 36.92 \\
\hline
\end{tabular}

\footnotetext{
${ }^{a}$ When changes in SOC applied to 30\% of total arable land in Europe (see Smith et al., 1997b, 1998a,b) and using the RothC simulation of SOC changes for the Geescroft Wilderness Experiment to predict SOC increases (Jenkinson et al., 1991).

${ }^{\mathrm{b}}$ IOM set from the regression of Falloon et al. (1998b), from the lower 95\% confidence interval of the regression, and from the upper $95 \%$ confidence interval of the regression.
} 
ties in the size of the IOM pool using a dynamic modelling approach could lead to errors in SOC predictions, these errors are less than those introduced by methods previously used for estimating regional carbon sequestration potential.

\section{Acknowledgements}

This work was supported by a grant from the UK Biotechnology and Biological Sciences Research Council. Thanks to Professor D.S. Jenkinson and Professor D.S. Powlson for discussion on the draft. IACR receives grant-aided support from the Biotechnology and Biological Sciences Research Council of the United Kingdom.

\section{References}

Coleman, K., Bradbury, N.J., Jenkinson, D.S., 1994. Calculating the input of inorganic matter to soil in three wooded sites. In: Welle, E., Szabolcs, I., Hettle, R.F. (Eds.), 7th International CIEC Symposium 'Agroforestry and Land Use Change in Industrialised Nations' proceedings. ISCF, Budapest, pp. 491-499.

Coleman, K., Jenkinson, D.S., 1996. RothC-26.3: a model for the turnover of carbon in soil. In: Powlson, D.S., Smith, P., Smith, J.U. (Eds.), Evaluation of soil organic matter models using existing, long-term datasets, NATO ASI Series I, Vol. 38. SpringerVerlag, Heidelberg, pp. 237-246.

Coleman, K., Jenkinson, D.S., Crocker, G.J., Grace, P.R., Klir, J., Körschens, M., Poulton, P.R., Richter, D.D., 1997. Simulating trends in soil organic carbon in long-term experiments using RothC-26.3. Geoderma 81, 29-44.

Falloon, P.D., Smith, P., Smith, J.U., Szabo, J., Coleman, K., Marshall, S., 1998a. Regional estimates of carbon sequestration potential: linking the Rothamsted Carbon Turnover model to GIS databases. Biology \& Fertility of Soils 27, 236-241.

Falloon, P., Smith, P., Coleman, K., Marshall, S., 1998b. Estimating the size of the inert organic matter pool for use in the Rothamsted carbon model. Soil Biology \& Biochemistry 30, 1207-1211.

Jenkinson, D.S., Coleman, K.C., 1994. Calculating the annual input of organic matter to soil from measurements of total organic carbon and radiocarbon. European Journal of Soil Science 45, 167174.

Jenkinson, D.S., Rayner, J.H., 1977. The turnover of soil organic matter in some of the Rothamsted classical experiments. Soil Science 123, 298-305.

Jenkinson, D.S., Adams, D.E., Wild, A., 1991. Model estimates of $\mathrm{CO}_{2}$ emissions from soil in response to global warming. Nature 351, 304-306.

Jenkinson, D.S., Bradbury, N.J., Coleman, K., 1994. How the Rothamsted Classical Experiments have been used to develop and test models for the turnover of carbon and nitrogen in soil. In: Leigh, R.A., Johnston, A.E. (Eds.), Long-term experiments in agricultural and ecological sciences. CAB International, Wallingford, pp. 117-138.

Jenkinson, D.S., Harkness, D.D., Vance, E.D., Adams, D.E., Harrison, A.F., 1992. Calculating net primary production and annual input of organic matter to soil from the amount and radiocarbon content of soil organic matter. Soil Biology and Biochemistry 24, 295-308.

Jenkinson, D.S., Harris, H.C., Ryan, J., McNeill, A.M., Pilbeam, C.J., Coleman, K., 1999a. Organic matter turnover in a calcareous clay soil from Syria under a two-course cereal rotation. Soil Biology and Biochemistry 31, 687-693.

Jenkinson, D.S., Hart, P.B.S., Rayner, J.H., Parry, L.C., 1987. Modelling the turnover of organic matter in long-term experiments at Rothamsted. INTECOL Bulletin 15, 1-8.

Jenkinson, D.S., Meredith, J., Kinyamario, J.I., Warren, G.P., Wong, M.T.H., Harkness, D.D., Bol, R., Coleman, K., 1999 b. Estimating net primary production from measurements made on soil organic matter. Ecology 80, 2762-2773.

Parshotam, A., Hewitt, A.E., 1995. Application of the Rothamsted carbon turnover model to soils in degraded semi-arid land in New Zealand. Environment International 21, 693-697.

Parshotam, A., Tate, K.R., Giltrap, D.J., 1995. Potential effects of climate and land-use change on soil carbon and $\mathrm{CO}_{2}$ emissions from New Zealand's indigenous forests and unimproved grasslands. Weather and Climate 15, 3-12.

Post, W.M., Emanuel, W.R., Zinke, P.J., Stangenberger, A.G., 1982. Soil carbon pools and world life zones. Nature 289, 156-159.

Schlesinger, W.M., 1995. An overview of the carbon cycle. In: Lal, R., Kimble, J., Levine, E., Stewart, B. (Eds.), Soils and Global Change. CRC Press, Boca Raton, USA, pp. 9-25.

Skjemstad, J.O., Clarke, P., Taylor, J.A., Oades, J.M., McGuire, S.G., 1996. The chemistry and nature of protected carbon in soil. Australian Journal of Soil Research 34, 251-271.

Smith, P., Powlson, D.S., Glendining, M.J., Smith, J.U., 1997 b. Potential for carbon sequestration in European soils: preliminary estimates for five scenarios using results from long-term experiments. Global Change Biology 3, 67-79.

Smith, P., Powlson, D.S., Glendining, M.J., Smith, J.U., 1998a. Opportunities and limitations for $\mathrm{C}$ sequestration in European agricultural soils through changes in management. In: Lal, R., Kimble, J., Follett, R.F., Stewart, B.A. (Eds.), Management of carbon sequestration in. CRC Press, Boca Raton, USA, pp. 143152.

Smith, P., Powlson, D.S., Glendining, M.J., Smith, J.U., 1998b. Preliminary estimates of the potential for carbon mitigation in European soils through no-till farming. Global Change Biology 4, 679-685.

Smith, J.U., Smith, P., Addiscott, T.M., 1996. Quantitative methods to evaluate and compare soil organic matter (SOM) models. In: Powlson, D.S., Smith, P., Smith, J.U. (Eds.), Evaluation of soil organic matter models using existing, long-term datasets, NATO ASI Series I, Vol. 38. Springer-Verlag, Heidelberg, pp. 183-202.

Smith, P., Smith, J.U., Powlson, D.S., McGill, W.B., Arah, J.R.M., Chertov, O.G., Coleman, K.C., Franko, U., Frolking, S., Jenkinson, D.S., Jensen, L.S., Kelly, R.H., Klein-Gunnewiek, H., Komarov, A.S., Li, C., Molina, J.A., Mueller, T., Parton, W.J., Thornley, J.M., Whitmore, A.P., 1997a. A comparison of the performance of nine soil organic matter models using seven longterm experimental datasets. Geoderma 81, 153-225.

Tate, K.R., Parshotam, A., Ross, D.J., 1995. Soil carbon storage and turnover in temperate forests and grasslands - a New Zealand perspective. Journal of Biogeography 22, 695-700.

Wang, Y.P., Polglase, P.J., 1995. Carbon balance in the tundra, boreal forest and humid tropical forest during climate change: scaling up from leaf physiology and soil carbon dynamics. Plant, Cell and Environment 18, 1226-1244. 